\title{
Do we need computer skills to use a computer? Evidence from Britain
}

Citation for published version (APA):

Borghans, L., \& ter Weel, B. J. (2006). Do we need computer skills to use a computer? Evidence from Britain. Labour - Review of Labour Economics and Industrial Relations, 20(3), 505-532. https://doi.org/10.1111/j.1467-9914.2006.00351.x

Document status and date:

Published: 01/01/2006

DOI:

10.1111/j.1467-9914.2006.00351.x

Document Version:

Publisher's PDF, also known as Version of record

\section{Please check the document version of this publication:}

- A submitted manuscript is the version of the article upon submission and before peer-review. There can be important differences between the submitted version and the official published version of record.

People interested in the research are advised to contact the author for the final version of the publication, or visit the DOI to the publisher's website.

- The final author version and the galley proof are versions of the publication after peer review.

- The final published version features the final layout of the paper including the volume, issue and page numbers.

Link to publication

\footnotetext{
General rights rights.

- You may freely distribute the URL identifying the publication in the public portal. please follow below link for the End User Agreement:

www.umlib.nl/taverne-license

Take down policy

If you believe that this document breaches copyright please contact us at:

repository@maastrichtuniversity.nl

providing details and we will investigate your claim.
}

Copyright and moral rights for the publications made accessible in the public portal are retained by the authors and/or other copyright owners and it is a condition of accessing publications that users recognise and abide by the legal requirements associated with these

- Users may download and print one copy of any publication from the public portal for the purpose of private study or research.

- You may not further distribute the material or use it for any profit-making activity or commercial gain

If the publication is distributed under the terms of Article $25 \mathrm{fa}$ of the Dutch Copyright Act, indicated by the "Taverne" license above, 


\section{Do We Need Computer Skills to Use a Computer? Evidence from Britain}

\section{Lex Borghans - Bas ter Weel}

Abstract. Using cross-section data from the 1997 Skills Survey of the Employed British Workforce, we examine the labour-market returns to self-assessed computer skills in Britain. Many researchers, using information on computer technology use, have concluded that wage differentials between computer users and nonusers might, among others, be due to differences in the embodiment of computer skills. Using unique information on the importance, level of sophistication, and effectiveness of computer technology use, we show that computer skills do not yield significant labour-market returns for most types of use. Examining the returns to computer skills at different levels of sophistication of use yields estimates suggesting returns to computer skills at the highest level of sophistication of use only.

\section{Introduction}

Most of us recognize the frustration if the computer does on many occasions not seem to do what we want it to do. It is even

Lex Borghans - Bas ter Weel (author for correspondence), Department of Economics and Maastricht Economic Research Institute on Innovation and Technology (MERIT), Maastricht University, PO Box 616, 6200MD Maastricht, the Netherlands. E-mail: b.terweel@merit.unimaas.nl.

We would like to thank the editor and the referees, Daron Acemoglu, Jim Allen, Josh Angrist, David Autor, Eli Berman, Allard Bruinshoofd, Francis Green, Hans Heijke, Hugo Hollanders, Larry Katz, Francis Kramarz, Alan Krueger, Victor Lavy, Jasper van Loo, Paul Miller, Richard Murnane, Steve Pischke, Arthur van Soest, Luc Soete, and Bruce Weinberg, as well as seminar participants at CentER, the Dutch Central Bank, the London School of Economics, and Maastricht University for helpful comments and suggestions on an earlier draft of this paper. In addition, we are most grateful to Francis Green and Alan Felstead for providing us with the data from the 1997 Skills Survey of the Employed British Workforce and for their help in explaining some of the variables. Financial support from the Netherlands Organization for Scientific Research (NWO) is also gratefully acknowledged. 
more demoralizing if a fellow worker always seems to be able to correct our computer disability at such instances and tell us exactly where we went wrong and how to proceed. Such experiences suggest that one needs computer skills to use a computer, as one has to have some understanding of how to operate the computer to perform computerized job activities at work. An interesting way to look at this problem is to investigate whether and if so what computer skills are rewarded by the employer or, put differently, whether and which computer skills yield labour-market returns. The present paper presents such an analysis.

Since Krueger's (1993) analysis, showing that computer users earn substantially higher wages than non-users, the returns to computer skills have been of interest to many researchers and policy makers. One interpretation of these findings has been that returns to computer skills might explain a substantial part of these higher wages. ${ }^{1}$ In this paper we examine the labour-market value of computer skills using information from the 1997 Skills Survey of the Employed British Workforce. This data set contains unique information about the self-assessed importance, level of sophistication, and effectiveness of computer technology use at work.

At least two features of our analysis set it apart from previous studies. First, we explore direct measures of the importance, level of sophistication, and effectiveness of computer use at the worker's job, which allows us to analyse in a direct way the computer skills needed to perform the job. Previous studies (e.g. Bell, 1996; DiNardo and Pischke, 1996; Hamilton, 1997) have used data containing only dummy variables for computer knowledge or computer ability as a rough proxy for computer skills (see Section 2 for more details). Furthermore, these studies were only able to explore data on computer skills without explicitly being able to relate these skills to jobs, which led to respondents having computer skills but not using a computer at work and, more remarkably, to respondents using a computer at work without possessing computer skills. Second, we estimate the importance and effectiveness of computer use within levels of sophistication of computer use. In this way, we distinguish between workers using computer technology for simple tasks, such as printing out an invoice, and workers using computers for sophisticated tasks, such as programming and developing software. Addressing labour-market returns to computer skills at different levels of sophistication is important for three reasons. First, it seems less likely that a worker using a computer to email receives large returns to the ability to do so, whereas it seems more likely 
that a software engineer receives returns to the ability to develop new computer applications. Second, the way in which computer technology is used at work is related to other aspects of the job as well: differences in average wages between different types of computer users might therefore be due to other differences in worker characteristics. Third, some authors interpret the computer wage premium, as observed by Krueger (1993), as a direct bonus for computer use, which is not related to worker characteristics, referring to arguments of limited competition and profit sharing. By controlling for the level of sophistication of computer use we are able to disentangle skill effects from pure use effects.

From this perspective, it is important to analyse whether workers use computer technology because they embody computer skills or whether computer use leads to acquiring computer skills. Although comparative advantages of people with computer skills might allocate them to jobs in which computers are more heavily used - so returns to computer skills will for a non-negligible part be reflected in the allocation of workers - analyses of within-group differences are a more appropriate tool to investigate our research question. Even if skills as such do not yield labour-market returns, one would expect users to acquire skills just by experience and learning by doing. ${ }^{2}$ Hence, the main problem is that if computer use is more common among more productive workers, a spurious correlation between computer skills and wages might show up in the data. The other way around, the use of computer technology might be a necessary condition to be paid for having computer skills.

Therefore, the strategy of analysing the returns to computer skills is twofold. First, the returns to computer skills within different levels of sophistication are investigated. These estimates yield information about the returns to computer skills not by comparing computer users and non-users, but by comparing different workers using the technology for similar purposes. Second, the question whether workers use computers because of their computer skills or whether they got computer skilled once they adopted the technology is analysed by focusing on the returns to computer skills of those workers who use the computer for a while. In this way, spurious correlations between the relatively low computer skills of recent users and their selective characteristics are likely to be avoided.

Our findings can be summarized as follows. Workers using computers at work earn substantially higher wages than non-users (20.6 per cent). The more important computer use and the higher the level 
of sophistication, the higher the wage differential between computer users and non-users. However, these wage differentials cannot be explained by differences in the embodiment of computer skills among different workers. Investigating average wages between categories of effectiveness and sophistication of use and the returns to computer skills does not yield statistically significant differences between workers who are always able to operate the computer effectively and workers only sometimes being able to use the computer effectively. Investigating the returns to computer skills for different levels of sophistication also reveals that most computer skills do not yield labour-market returns. Only workers operating computers at the most advanced level - i.e. using a computer syntax and/or formulae for programming and developing software - receive a return on their computer skills. Finally, our estimates reveal that workers using a computer for a longer time are more effective than recent users, suggesting on-the-job learning by doing rather than large investments in computer skills. These results do not seem to be due to measurement problems in measuring computer skills.

This paper proceeds as follows. Section 2 presents the data and discusses issues concerning the measurement of computer skills. Section 3 shows the estimation results and addresses the robustness of our results. Section 4 presents a general discussion of the results and concludes.

\section{Data and skill measurement}

\subsection{Data}

The data used in this paper have been collected in a survey, conducted in the first half of 1997, called the Skills Survey of the Employed British Workforce. The survey includes a representative number of workers $(2,467)$ from Britain aged 18-60 (see the Data Appendix for descriptive statistics). Exclusion of cases with missing observations on relevant variables gives us 2,421 cases. Participants were asked several dozens of questions on their labour-market situation during face-to-face interviews to obtain information on various aspects of their jobs including qualifications, responsibilities, the importance and ability to carry out certain tasks at work, and training. ${ }^{3}$

Of interest for the purpose of our analysis are the detailed questions concerning the importance, level of sophistication, and 
effectiveness of computer use. Particularly the information on the latter two is unique. With respect to the level of sophistication of computer use, Entorf and Kramarz (1997) and Entorf et al. (1999) use the Enquête sur la Technique et l'Organisation du Travail auprès des Travailleurs Occupés, in which they distinguish three levels of computer use related to the autonomy of each worker. This is an indirect measure of the level of sophistication of computer use because it relates to the job in general, whereas the data used in this paper relate the level of sophistication of computer use to the worker's computerized tasks. The effectiveness of computer use has been measured indirectly as computer ability (Bell, 1996) or computer knowledge (DiNardo and Pischke, 1996; Hamilton, 1997). Bell uses data from the UK National Child Development Study ${ }^{4}$ and DiNardo and Pischke use data from the West German Qualification and Career Survey conducted by the Federal Institute for Vocational Training. In these data information on both computer use and computer knowledge is available. Hamilton uses variables from the 1986 High School and Beyond Survey indicating whether an individual has ever used software packages or a computer language to program. These measures are related to computer ability or skills in a general sense, but do not necessarily reveal information about the effectiveness of conducting computerized job activities. The information on the effectiveness of computer use from the data used and analysed in this paper is directly related to the computerized tasks performed by the worker. By measuring its effectiveness, a proxy for the worker's computer skills directly related to the job is obtained.

With regard to the importance of computer use, the following question has been asked: 'In your job, how important is using a computer, PC, or other types of computerized equipment?' The response scale offered is the following: 'essential', 'very important', 'fairly important', 'not very important', and 'not at all important'.

With respect to the level of sophistication of computer use, the following question has been asked: 'Which of the following best describes your use of computers or computerized equipment in your job?' The answers are divided into four different levels of sophistication at which computers are being occupied. 'Simple' use indicates 'straightforward use, e.g. using a computer for straightforward routine procedures such as printing out an invoice in a shop'; 'moderate' use means 'e.g. using a computer for word processing and/or spreadsheets or communicating with others by email'; 'complex' use is defined as 'e.g. using a computer for 
analysing information of design, including use of computer-aided design or statistical analysis packages'; and 'advanced' use is described as 'e.g. using a computer syntax and/or formulae for programming and developing software'.

The effectiveness of computer use is measured by the answers to the following question: 'When your job involves using a computer, $\mathrm{PC}$, or other type of computerized equipment, are you able to do this effectively?' Five possible answer categories were offered: 'always', 'nearly always', 'often', 'sometimes', and 'hardly ever'.

\subsection{Skill measurement}

The question used to measure the effectiveness of computer use - to approximate computer skills - has been subject of substantial debate among economists, psychologists, and sociologists, especially in the literature regarding the importance of language skills (e.g. Berman et al., 2003; Borjas, 1994; Chiswick and Miller, 1995; Dustmann and van Soest, 2001; Willis and Rosen, 1979). Surveys relying upon the respondent's self-assessment to acquire information about ability and skill often use a question like 'how would you rate your current writing skills in English?' The response alternatives are 'very good', 'good', 'fair', 'poor', or 'cannot write in English'. Such answers, in the absence of independent verification (e.g. objective tests), question the reliability of the responses for reasons of social desirability and self-referencing, which encourage over-estimation of ability and skill and are likely to bias the data in unidentifiable ways. ${ }^{?}$

For academic abilities and skills such as reading, writing, and mathematics, it is possible to measure a respondent's skills by test items. This has the obvious advantage that for all respondents the skills are measured in an identical way. Whereas the Organization for Economic Cooperation and Development (OECD) will use this approach for numeracy and literacy skills in the forthcoming Life Skills Survey, computer skills seem to be too much context- or task-related to allow for a general set of test items [see, for example, OECD (2000) for a discussion].

Although the approach taken in the data used in this paper also relies upon the self-assessment of the respondent, the main strategy has been to assess and approximate skills through questions on several tasks a respondent has to carry out at work, rather than directly asking respondents to evaluate their own skill level. The main reason to use this approach has been that being asked to 
describe whether one carries out the tasks at work effectively seems to be much less subject to self-esteem than being asked to assess one's own abilities. Furthermore, the questions are directly linked to the tasks that must be fulfilled, which is likely to directly influence the performance of the job and therefore the wage. Rather than collecting information about an abstract skill, the question is directly addressed to the success of using a computer, i.e. the question is competence-based. Finally, Spenner (1990) reports evidence from a number of studies finding high correlations between self-assessed measures of skill obtained by this method and similar ways of questioning and measures obtained from objective judgements by experts and external expert systems used to develop, for example, the Dictionary of Occupational Titles. We will empirically address the validity and robustness of the use of this skill measure in Section 3.4.

\subsection{Descriptives}

Table 1 reports the distribution of the answers to the three computer questions. Panel A reports information about the importance of computer use, Panels $\mathrm{B}$ and $\mathrm{C}$ report the distribution of answers of computer users on their level of sophistication and effectiveness of use. Of the sample population, 69.2 per cent use a computer at work, which is comparable to figures reported for Germany and the USA in the late 1990s (e.g. Borghans and ter Weel, 2002). The numbers reported in Panel A indicate that computer use is 'essential' in almost one-third of all cases, and in 14.7 per cent it is regarded as 'very important'; 11.5 per cent of the respondents reported that computer use is 'not very important' in their jobs.

The level of sophistication of computer use, reported in Panel B, is skewed towards 'simple' and 'moderate' tasks like routine procedures, such as printing out an invoice in a shop and using a computer for word processing and/or spreadsheets or communicating with others by email. Only a relatively small portion (3.4 per cent) of the workforce uses computer technology at the 'advanced' level, i.e. using a computer syntax and/or formulae for programming and developing software. The majority of workers uses computer technology to do moderately sophisticated or simple tasks (53.6 per cent of the sample population). The correlation (standard error) between the importance and level of sophistication of computer use is very strong and equals $0.826(0.000)$. 
Table 1. Distribution of the answers to the questions about the importance, level of sophistication, and effectiveness of computer use

Panel A

Importance: 'In your job, how important is using a computer, PC, or other types of computerized equipment?'

1. Essential

2. Very important

3. Fairly important

\section{Panel B}

Sophistication: 'Which of the following best describes your use of computers or computerized equipment in your job?'

1. Advanced

2. Complex

3. Moderate

4. Simple

\section{Panel C}

Effectiveness: 'When your job involves using a computer, PC, or other type of computerized equipment, are you able to do this effectively?'

1. Always

2. Nearly always

3. Often

4. Sometimes

5. Hardly ever

Notes: All data are taken from the 1997 Skills Survey of the Employed British Workforce. $n=2,421$.

The figures reported in Panel $\mathrm{C}$ show that more than half of the workers in the sample are relatively well able to use the computer effectively ('always' and 'nearly always'). Among those who use a computer, there seems to be a relatively large portion who are often not able to carry out the computerized part of the job effectively: 10.2 per cent of the total sample population answers 'sometimes' or 'hardly ever' being able to use computer technology effectively. The correlation between the effectiveness and importance of computer 
use is very strong and equals $0.858(0.000)$. The same goes for the correlation between the effectiveness and sophistication of computer use: 0.807 (0.000).

Table 2 reports for each pair of the importance and level of sophistication of computer technology use the effectiveness of use. The first number for each level of sophistication is the percentage of workers in that cell answering 'always' to the effectiveness questions, whereas the second number is the percentage of workers in that cell answering 'hardly ever'. The numbers in this table show that workers in jobs in which computer technology is more important and more sophisticated seem to be more able to perform computerized tasks effectively. In terms of data measurement these numbers also reveal that the questions on computer use have been answered consistently and in line with the a priori expectation that workers being relatively effective in using computer technology use it for more important tasks and operate it at a higher level of sophistication. This is also revealed in the high correlation coefficients between the three computer questions.

Table 3 is equivalent to Table 2 but reports the log hourly wages of these workers. The information about wages suggests that there is surprisingly little variation in hourly wages based on the effectiveness of computer use. Sometimes the average wages are even higher for those who report to be 'hardly ever' able to use computer technology effectively. Comparison across levels of sophistication seems to suggest that workers who use computer technology at more advanced levels earn on average higher wages. Looking across levels of importance of computer use suggests a similar pattern except for the category of computer-using workers for which computer use is not important. Also within moderate and simple levels of computer use the picture blurs in the sense that wages are not positively correlated with the ability to use computer technology at work.

\section{Computer use and wages}

Most empirical attempts to estimate the returns to computer skills are based on information about computer use, which is applied as a proxy for computer skills. The underlying assumption to do so is that workers who embody more skills will be allocated to jobs in which computer skills are required. This strategy only works when computer skills are indeed the only determinant in the 


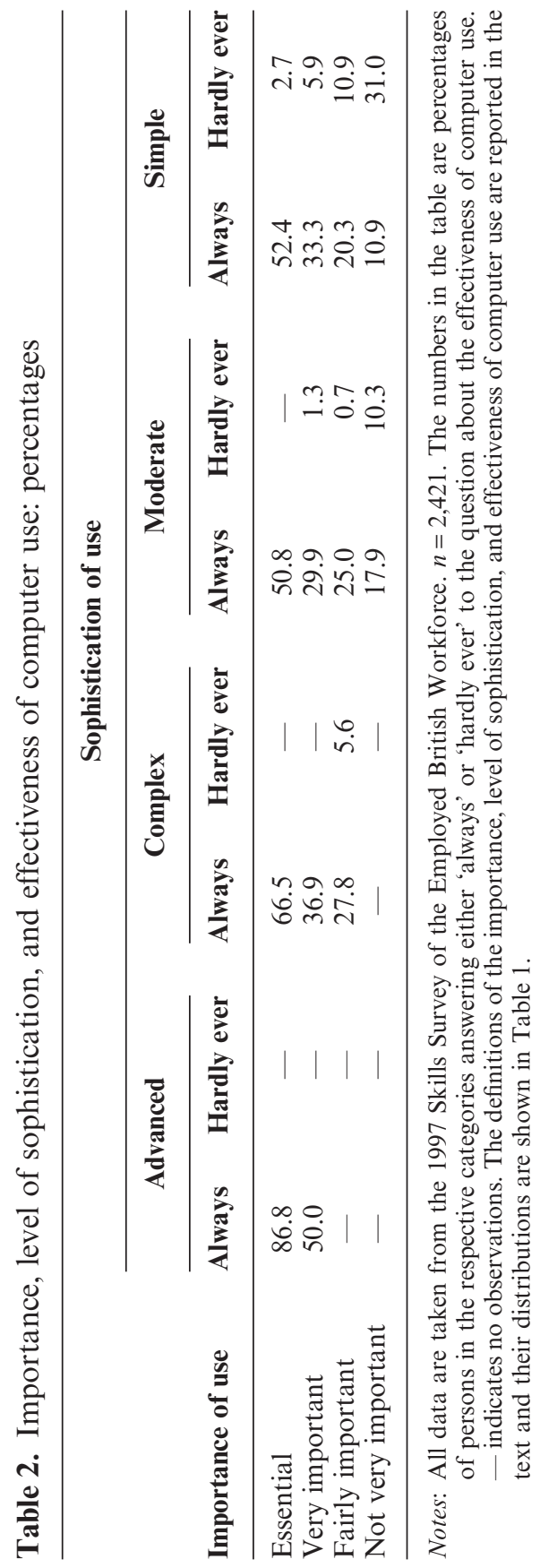




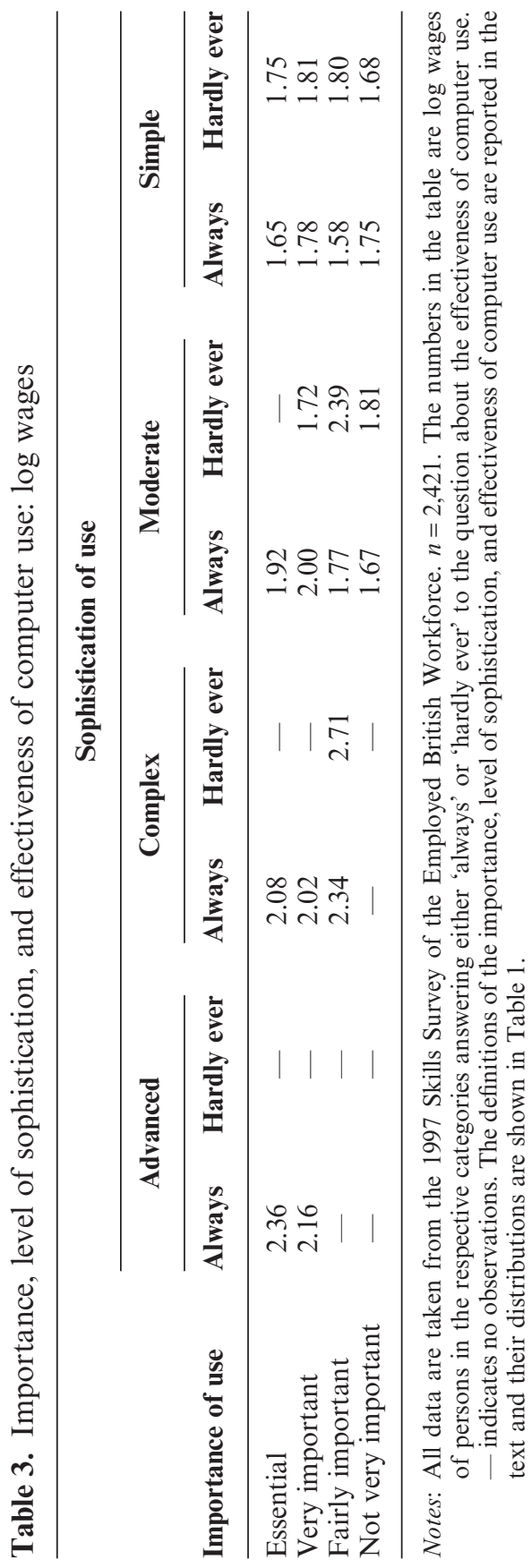


allocation process. If this is not the case, the estimated returns to computer use will also include all wage differentials associated with other relevant factors in the allocation of workers to jobs or might include wage effects if computer use per se related to noncompetitive labour market effects and profit sharing between worker and firm.

As an alternative approach, one could estimate the relationship between wages and a direct measure of computer skills. The main problem of this strategy is that if the use of computer technology at work reveals characteristics of the worker that have nothing to do with the related skills, and if experience is increasing in use, a positive correlation between skills and wages could be a reflection of unobserved heterogeneity, rather than being a reflection of returns to skills. Even very trivial skills might turn out to have a return: if you are aware of the room numbers of people in the board of General Motors, you are probably working there, so your wage will be high.

The strategy we adopt here to estimate the returns to skills is to investigate the relationship between skills and wages within a group of workers who use computer technology at the same level of sophistication. ${ }^{8}$ In this way, we distinguish between workers using the computer equipment for relatively simple tasks from workers carrying out relatively complex tasks, which is likely to have much more impact on their experience. For example, there is a large difference in using computer technology for tasks such as printing out an invoice or for tasks such as programming and developing software. This way we can also investigate which computer skills are rewarded.

\subsection{Basic estimates}

To examine the returns to the importance, level of sophistication, and effectiveness of computer use, we first run standard [ordinary least squares (OLS)] wage regressions and augment the standard cross-sectional wage equation by including a dummy variable for computer use. The wage equation then looks like

$$
\ln W_{i}=\mathrm{D}+\alpha X_{i}+\beta C_{i}+\varepsilon_{i},
$$

where $\ln W_{i}$ is the log of the gross hourly wage, $X_{i}$ is a vector of observed characteristics, and $C_{i}$ represents a dummy variable that 
Table 4. Estimates of the effect of computers on pay [dependent variable: log (hourly wage)]

\begin{tabular}{|c|c|c|c|c|}
\hline 1 & $\begin{array}{c}2 \\
\text { Dummy } \\
\text { computer use }\end{array}$ & $\begin{array}{c}3 \\
\text { Importance } \\
\text { computer use }\end{array}$ & $\begin{array}{c}4 \\
\text { Sophistication } \\
\text { computer use }\end{array}$ & $\begin{array}{c}\quad 5 \\
\text { Effectiveness } \\
\text { computer use }\end{array}$ \\
\hline \multicolumn{5}{|l|}{ Education } \\
\hline University & $0.390(0.044)^{* *}$ & $0.367(0.044)^{* *}$ & $0.343(0.044)^{* *}$ & $0.382(0.044)^{* *}$ \\
\hline Professional & $0.249(0.040)^{* *}$ & $0.244(0.040)^{* *}$ & $0.228(0.040)^{* *}$ & $0.244(0.040)^{* *}$ \\
\hline NVQ3 & $0.162(0.034)^{* *}$ & $0.150(0.034)^{* *}$ & $0.142(0.034)^{* *}$ & $0.159(0.035)^{* *}$ \\
\hline NVQ2 & $0.131(0.029)^{* *}$ & $0.126(0.029)^{* *}$ & $0.121(0.029)^{* *}$ & $0.128(0.029)^{* *}$ \\
\hline NVQ1 & $0.047(0.040)$ & $0.042(0.040)$ & $0.045(0.039)$ & $0.042(0.040)$ \\
\hline Experience & $0.010(0.002)^{* *}$ & $0.010(0.002)^{* *}$ & $0.010(0.002)^{* *}$ & $0.010(0.002)^{* *}$ \\
\hline Experience squared & $-0.003(0.001)^{* *}$ & $-0.003(0.000)$ & $-0.003(0.000)^{* *}$ & $-0.003(0.000)^{* *}$ \\
\hline Computer use (dummy) & $0.194(0.025)^{* *}$ & & & \\
\hline \multicolumn{5}{|c|}{ Importance of computer use } \\
\hline Essential & & $0.293(0.030)^{* *}$ & & \\
\hline Very important & & $0.212(0.033)^{* *}$ & & \\
\hline Fairly important & & $0.137(0.034)^{* *}$ & & \\
\hline Not very important & & $0.115(0.034)^{* *}$ & & \\
\hline \multicolumn{5}{|l|}{ Sophistication of use } \\
\hline Advanced & & & $0.386(0.057)^{* *}$ & \\
\hline Complex & & & $0.296(0.036)^{* *}$ & \\
\hline Moderate & & & $0.256(0.030)^{* *}$ & \\
\hline Simple & & & $0.115(0.027)^{* *}$ & \\
\hline \multicolumn{5}{|l|}{ Effectiveness of use } \\
\hline Always & & & & $0.206(0.030)^{* *}$ \\
\hline Nearly always & & & & $0.209(0.030)^{* *}$ \\
\hline Often & & & & $0.224(0.041)^{* *}$ \\
\hline Sometimes & & & & $0.200(0.045)^{* *}$ \\
\hline Hardly ever & & & & $0.082(0.049)$ \\
\hline Occupational dummies & Yes & Yes & Yes & Yes \\
\hline Industry dummies & Yes & Yes & Yes & Yes \\
\hline Adjusted $R^{2}$ & 0.395 & 0.405 & 0.406 & 0.395 \\
\hline
\end{tabular}

Notes: All data are taken from the Skills Survey of the Employed British Workforce. $n=2,421$. All regressions are performed by OLS (standard errors are in parentheses). ** Significant at the 1 per cent level; * significant at the 5 per cent level. All regressions also include an unreported intercept and control for gender, being married, married $\times$ gender, being a union member, and being a supervisor. Educational levels are classified in five categories, which correspond to the UK classifications (workers without a qualification are used as the reference group). Occupations and sectors are listed in the Appendix.

equals 1 if worker $i$ uses a computer at work, and 0 otherwise; $\alpha$ and $\beta$ are the estimated parameters, $\mathrm{D}$ is a constant, and $\varepsilon_{i}$ is an error term with the usual assumptions.

Column 2 of Table 4 reports the results of estimating this equation. Besides the dummy variable for computer use, the regression equation includes the usual labour-market covariates, such as educational level (ranging from a university degree to the National Vocational Qualification (NVQ1) level, where workers without any qualification are the reference group), experience and experience 
squared, and occupational and sector dummies, and the following unreported variables: gender, being married, married $\times$ gender, being a union member, and being a supervisor. The equation also includes an unreported intercept. ${ }^{9}$ The wage differential between computer users and non-users equals 21.4 per cent $[\exp (0.194)-1]$, which is consistent with the findings of others. ${ }^{10}$ The regression results reported in column 3 show estimates for the effects of the importance of computer use on wages. The coefficients reveal that, relative to a worker not using a computer, the returns to computer use are higher the higher the importance of computer use. The same conclusion can be drawn from the estimates presented in column 4: the level of sophistication of computer use exerts a positive impact on the wages of computer users relative to non-users.

Finally, column 5 reports the coefficients from including the effectiveness of computer use into the regression equation. The coefficients still suggest a substantial wage differential between computer users and non-users but the coefficients for the effectiveness of computer use at the four highest levels do not significantly differ from each other. Only workers reporting to be 'hardly ever' able to use the computer effectively do not earn significantly higher wages than non-users, although the point estimate is quite large and significant at the 10 per cent level, suggesting that workers who are hardly ever able to use a computer effectively earn almost 10 per cent higher wages than similar workers who do not use a computer.

The results from estimating these four straightforward wage equations, putting forward the returns to different aspects of computer use, are interesting. The positive correlation between the level of sophistication of use and wages in Table 4 and the positive relation between the level of sophistication and effectiveness of computer use in Table 2 would lead one to predict a positive correlation between the effectiveness of computer use and wages too. The same argument applies to the importance of computer use, because if computer use is reported to be relatively important, workers are relatively effective in using the computer. However, this effect is not reflected in the returns to the effectiveness of computer use and becomes already to the surface when reviewing the numbers in Table 3 . The result in column 5 would lead to the conclusion that the ability to use a computer does not matter for wage outcomes, and that the wage differential between computer users and non-users cannot be attributed to differences in computer skills. 


\subsection{Sophistication and effectiveness}

To draw inferences about the returns to computer skills, we separate the higher wages computer users obtain from the effectiveness of their computer use. To do so, we estimate returns to the effectiveness of computer use within each of the four levels of sophistication of computer use. In this way, we distinguish the programmer and software engineer, using a computer syntax and/or formulae for programming and developing software, from the secretary, using the computer for emailing and word processing. As the importance and the level of sophistication of computer use are correlated with the effectiveness of computer use, the coefficients on the effectiveness might interfere with the relationship between computer use as such and wages. We therefore choose a specification for this wage equation as flexible as possible.

We estimate three different models. The first model includes the 16 possible combinations of the importance of computer use (essential, very important, fairly important, and not very important) and the level of sophistication of computer use (advanced, complex, moderate, and simple). Workers not using a computer at work are used as the reference group. The second model includes 20 combinations of the effectiveness of computer use (always, nearly always, often, sometimes, and hardly ever) and the level of sophistication. Again those workers not using computers are taken as the reference group. Finally, we estimate a model including 16 dummy variables in which we combine the importance and effectiveness of computer use (important and effective, important and ineffective, unimportant and effective, and unimportant and ineffective) with the level of sophistication, using non-users as the reference group.

When constructing the variables, it turns out that there are no computer users reporting their computer use as fairly important and not very important at the advanced level of sophistication. In addition, at the complex level of sophistication, no computer user regards his computer use as not very important. For the effectiveness of computer use, it turns out that within the advanced level of computer use only workers are present reporting their computer use to be always and nearly always effective. Similarly, at the complex level of computer use, there are no workers reporting that they are hardly ever able to use the computer effectively. For the combination of importance and effectiveness, we only have observations within the advanced level of sophistication when computer use is both important and effective. 
Table 5 reports the estimates from these wage equations. Panel A includes the importance of computer use for each level of sophistication, Panel B the effectiveness of computer use, and Panel $\mathrm{C}$ a composite measure of the importance and effectiveness of computer use.

The estimates reported in Panel A of Table 5 suggest that at the advanced level of sophistication of computer use the workers for whom computer use is essential gain most (in terms of wages) from computer use. Although the point estimate is higher, the coefficient cannot be statistically distinguished from the coefficient for workers reporting that computer use is very important. For workers using the computer at the complex level of sophistication a similar effect is obtained, although the coefficient for workers whose computer use is only fairly important is comparable. Going down the level of sophistication of computer use further reveals similar patterns. Hence, controlling for the level of sophistication shows that the effects of the importance of computer use on wages are rather limited. Although the point estimates suggest a higher wage if computer use is more important, it is in most instances not possible to statistically discriminate between the coefficients within each level of sophistication.

Panel B of Table 5 presents a similar analysis of the effectiveness of computer use. For the advanced level of sophistication of computer use, workers whose effectiveness in using the computer is highest obtain the highest wages. This result is not surprising given the occupations for which advanced computer use is required. These are mostly workers using the computer as their main job activity, such as programming and developing software, etc. Hence, being effective in using the computer leads to higher productivity and wages. If the computer is used for complex tasks, the level of effectiveness of use does not seem to be of main importance. Workers reporting being often able to use the computer effectively gain most from computer use. For moderate and simple levels of sophistication of computer use, workers reporting being sometimes able to use the computer effectively benefit to the largest extent, although the coefficients are not significantly different from higher levels of effectiveness. Looking at the rather flat pattern of regression coefficients from Table 4, these humpshaped patterns are to be expected because there is a positive relationship between the level of sophistication of computer use and wages and between the sophistication of use and the effectiveness of computer use (Table 2). Therefore, a flat pattern for the overall 


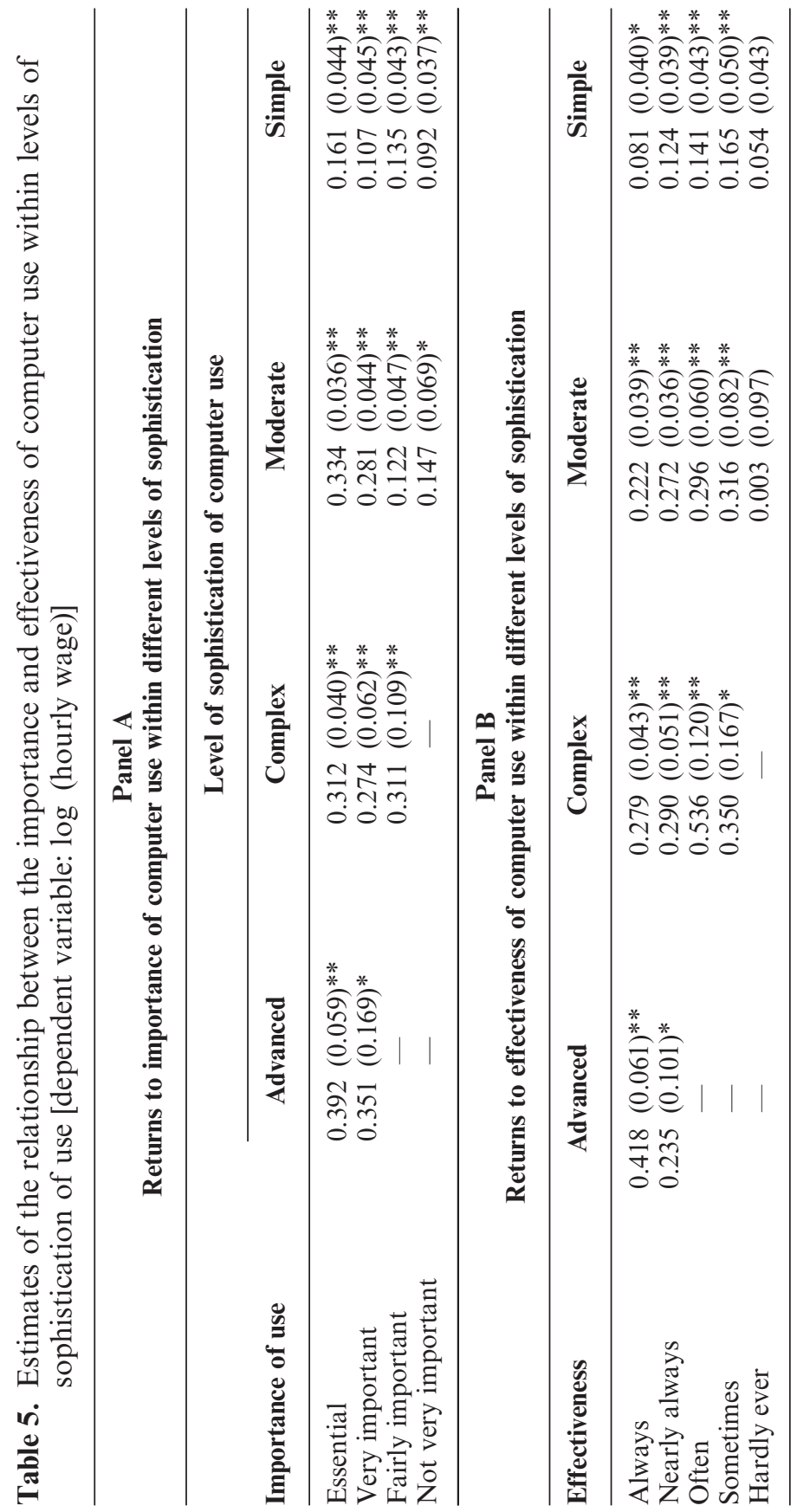




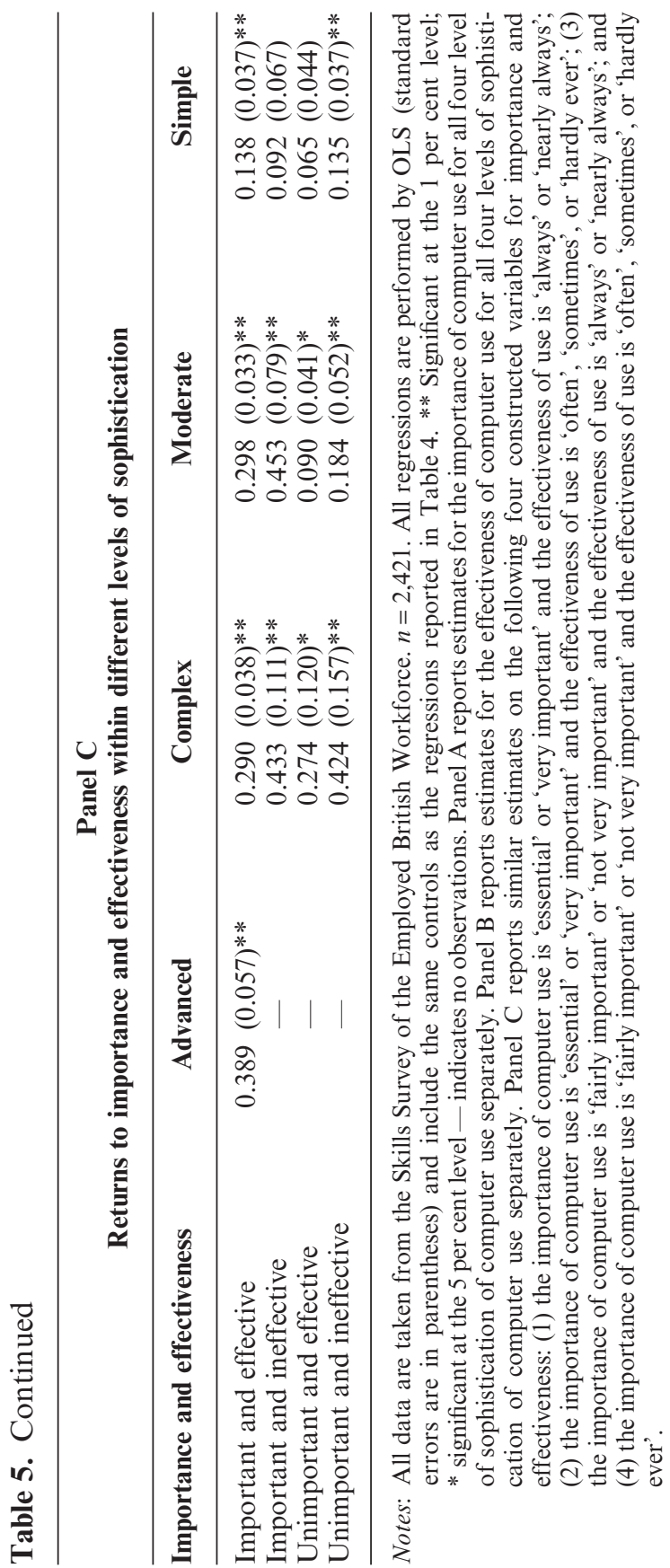


relationship between computer skills and wages can only exist if within some levels of sophistication more skills are associated with lower wages.

The results presented in Panels A and B could be shaped by the interaction between the importance of computer use and its effectiveness. We therefore control for the possibility of interaction effects. As the number of possible interaction effects is too large, we constructed four composite measures. First, computer use might be both important and effective. This is defined as workers reporting essential or very important with respect to the importance of computer use and answering always and nearly always if asked about their effectiveness of computer use. Second, computer use might be important and ineffective. Ineffectiveness is defined as workers responding often, sometimes, or hardly ever on the question about the effectiveness of computer use. Third, computer use might be unimportant and effective. Unimportance is defined as workers reporting their computer use to be fairly important or not very important. Fourth, computer use might be unimportant and ineffective.

Panel $\mathrm{C}$ of Table 5 reports the effects of the four composite measures on wages within each level of sophistication of computer use. The results are consistent with the estimates reported in Panels $\mathrm{A}$ and $\mathrm{B}$. If using a computer is relatively important, the wage gain is highest. For the estimates it does not seem to matter very much whether the use of the computer is effective or not. Hence, the importance of computer use explains the higher wages of computer users better than the effectiveness of computer use, which is consistent with the estimates reported in Table 3 and runs counter to the perception of those propagating the importance of computer skills for labour-market success.

Our empirical strategy is focused on separating a skill effect from effects of computer use on wages through unobserved characteristics or profit sharing. It cannot be excluded that any effect of computer skills on wages reflects skills that are highly correlated with computer skills. As for most levels of sophistication our finding is that computer skills do not affect wages, it can be concluded that also such a wider set of computer-related skills does not affect wages. For workers who use computers at a sophisticated level, there seems to be a skill premium. In this case we cannot exclude in statistical terms that specific skills, which are very related to computer skills, rather than pure computer skills, generate (part of) this wage premium. 


\subsection{Experience with using computers}

The only regression coefficient in Table 4 that suggests positive returns to computer skills is the significantly lower wage premium for the computer users with the lowest effectiveness of computer use. The reason for this pattern might be that many of those who report a low effectiveness of computer use started to use the computer only recently. The wages are therefore likely to reflect the selective characteristics of this newly group of computer users rather than a penalty for low skills as such.

We are able to analyse this because the data include information on the use of computers 5 years before the survey (i.e. in 1992). If we exclude those workers who did not use a computer 5 years ago, the regression coefficients of a regression similar to the one reported in column 5 of Table 4 are the following (standard errors in parentheses): 0.298 (0.054), 0.327 (0.054), 0.315 (0.096), 0.297 (0.080), and 0.338 (0.111), respectively. Particularly the coefficient for the least computer skilled workers has gone up dramatically, which means that there are no differences in the returns between the skill levels. Excluding recent users from the extended analysis reported in Table 5 has similar effects: the wage premium for the lowest level of effectiveness becomes similar to the premiums for higher skill levels and within each level of sophistication computer skills are only rewarded at the highest level of sophistication. These estimates suggest that workers who use a computer for a longer time receive the same wage premium, regardless of their computer skills. This implies that differences in computer skills between workers do not explain differences in wages for most computer technology users.

Our interpretation of these coefficients is that recent users are least effective in using computers. Their lower wages are however not caused by this lack of computer skills but origin from other sources.

\subsection{Validity of the skill measure}

A concern about the regression results is whether the information used for the effectiveness of computer use is measured adequately. If the measure would be poor, a lack of significant results from the regressions reported in Tables 4 and 5 could demonstrate the low quality of the measure rather than a lack of returns to the effectiveness of computer use at work. Although subjective measurement will always suffer to some extent from limited self-knowledge and 
possible exaggerations of a worker's ability and skill level, the measure is likely to be adequate for the following three reasons.

First, comparing the estimation results of the effectiveness of computer use with other measures from the same survey yields estimates in line with a priori expectations. In particular, workers grade themselves lower with regard to skills and tasks viewed upon as relatively difficult, such as analytical thinking and carrying out complex and mathematical problems.

Second, the positive relation between the importance, level of sophistication, and effectiveness of computer use reported in Table 2 rejects the suspicion that the self-assessed computer skill measure is biased.

Finally, Table 6 reports regression results for effectiveness questions on five other job items using the same subjective measure and performed using the same controls as the regression in column 5 of Table 4. The questions whether a worker is able to perform certain job activities effectively have been asked for the following job items:

(1) analysing complex problems; (2) helping other team members; (3) making speeches or presentations; (4) writing short documents with correct spelling and grammar (e.g. short reports, letters, or memos); and (5) reading and understanding short documents such as short reports, letters, or memos. The estimates reported in Table 6 suggest that, unlike the estimates for effectiveness of computer use, higher levels of effectiveness yield higher labour-market returns. ${ }^{11}$

\section{Discussion and conclusion}

The main goal of this paper has been to investigate whether there are labour-market returns to computer skills and if so which computer skills yield returns. We have done so using unique and detailed information on the importance, level of sophistication, and effectiveness of computer use at work. The results from the empirical analysis presented in this paper confirm previous findings that computer users earn higher wages than non-users but adds to this that the effectiveness of computer use, used to approximate computer skills, does not yield labour-market returns in most cases. Analysing the returns to computer skills for different levels of sophistication of computer use yields estimates suggesting returns to computer skills at the advanced level of sophistication of use only. For 'ordinary' jobs in which computer technology is part of the job, there do not seem to be returns to computer skills. 
Table 6. Robustness of the skill measure [dependent variable: $\log$ (hourly wage)]

\begin{tabular}{lll}
\hline Skill measure & Effectiveness & Estimated returns \\
\hline Analysing complex problems & Always & $0.165(0.033)^{* *}$ \\
& Nearly always & $0.145(0.029)^{* *}$ \\
& Often & $0.123(0.036)^{* *}$ \\
& Sometimes & $0.064(0.024)^{*}$ \\
Helping other team members & Hardly ever & $0.052(0.052)$ \\
& Always & $0.150(0.039)^{* *}$ \\
& Nearly always & $0.193(0.039)^{* *}$ \\
& Often & $0.191(0.047)^{* *}$ \\
& Sometimes & $0.096(0.043)^{*}$ \\
Making speeches or presentations & Hardly ever & $0.066(0.111)$ \\
& Always & $0.198(0.037)^{* *}$ \\
& Nearly always & $0.169(0.030)^{* *}$ \\
& Often & $0.174(0.036)^{* *}$ \\
Writing short documents with & Sometimes & $0.097(0.037)^{*}$ \\
correct spelling and grammar & Hardly ever & $0.072(0.036)^{*}$ \\
& Always & $0.172(0.030)^{* *}$ \\
& Nearly always & $0.164(0.030)^{* *}$ \\
& Often & $0.096(0.043)^{*}$ \\
& Sometimes & $0.062(0.044)$ \\
Reading and understanding written & Hardly ever & $0.065(0.047)$ \\
materials & Always & $0.149(0.035)^{* *}$ \\
& Nearly always & $0.167(0.035)^{* *}$ \\
& Often & $0.129(0.050)^{*}$ \\
& Sometimes & $0.034(0.048)$ \\
& Hardly ever & $0.011(0.047)$ \\
\hline
\end{tabular}

Notes: All data are taken from the Skills Survey of the Employed British Workforce. $n=2,421$. All regressions are performed by OLS (standard errors are in parentheses). ** Significant at the 1 per cent level; * significant at the 5 per cent level. The regressions are similar to the one reported in Table 4, column 5 and include the same controls. The adjusted $R^{2}$ s are $0.378,0.376,0.382,0.380$, and 0.378 , respectively.

Our reading of these results is the following. First, what are valuable computer skills? Differences in computer skills between workers do not explain why workers using a computer earn higher wages than non-users. There are only returns to computer skills if computer technology is used in an advanced and complex manner. This suggests that the computerized job activities are of central importance only if the computer is occupied at the advanced level. In most instances, the computer is likely to be used for routine job activities, which are not particularly the motivation for hiring a worker and, as a result, the worker is not paid for the performance of 
these activities. This is consistent with casual observations, as most workers use the computer for secondary tasks - such as typing a manuscript, sending emails, and running regressions - only.

Second, a large part of the size of the coefficients reported in columns 3 and 4 in Table 4 seems to be due to computer use as such. This is also clear from the estimates in Table 5 where we show that within categories of use there are returns to complex and advanced computer use. It is beyond the scope of the present paper to go into the reasons why computer users earn higher wages than non-users, but the estimates in Chennells and Van Reenen (1997), Entorf and Kramarz (1997), and Entorf et al. (1999) suggest that computer users were already earning higher wages than non-users before using the technology. This is consistent with the view that employers use computers first in high-wage jobs to save on relatively expensive labour and explains why higher-educated and more experienced workers use computers. It is also consistent with our results, because we have shown that the recent computer users earn lower wages than workers already using computers for a longer period of time, which could be interpreted as those workers getting computers later because of their lower wages. So, the causal relationship between computer use and earnings is unclear. It might also be true that workers with higher wages are more likely to use computer technology to save on their expensive labour, a claim theoretically explored in Borghans and ter Weel (2004a) that reverses the causality of the relationship between wages and computer use. To investigate the causal relationship between computer technology use and earnings further, more empirical evidence needs to be collected and valid instruments need to be available. It might also be that complementarity between labour and capital determines computer use and the higher wages of computer users (e.g. Autor et al., 2003).

Third, the regression results suggest that the effectiveness of most computer use is a matter of learning by doing: computer skills do in general not yield labour-market returns but workers using the computer for a longer period of time are more effective in using it. This insight also leads to the conclusion that large investments in computer skills are unlikely to be very effective. Most computer skills are likely to be acquired by experience and rather easily learned when necessary at work.

Hence, our fellow worker - who is always able to show us how to use the computer effectively and to correct our mistakes - is obviously more computer skilled than we are, but is unlikely to 
receive a higher wage because of this superior effectiveness (unless he is a computer scientist with great computer skills).

\section{Data Appendix}

This appendix provides a number of salient details about the 1997 Skills Survey of the Employed British Workforce. In particular, it presents the percentages of persons in the survey with certain characteristics and the percentage computer users in those categories.

\begin{tabular}{|c|c|c|}
\hline Variable & $\begin{array}{c}\text { Percentage in } \\
\text { survey }\end{array}$ & $\begin{array}{c}\text { Percentage } \\
\text { computer users }\end{array}$ \\
\hline \multicolumn{3}{|l|}{ Gender } \\
\hline Male & 52.9 & 69.2 \\
\hline Female & 47.1 & 69.1 \\
\hline \multicolumn{3}{|l|}{ Age (years) } \\
\hline $20-29$ & 20.9 & 67.8 \\
\hline $30-39$ & 33.5 & 71.6 \\
\hline $40-49$ & 26.1 & 71.9 \\
\hline $50-60$ & 19.5 & 63.0 \\
\hline \multicolumn{3}{|l|}{ Education } \\
\hline University & 9.9 & 95.5 \\
\hline Professional & 12.4 & 88.9 \\
\hline NVQ3 & 15.2 & 75.1 \\
\hline NVQ2 & 34.5 & 71.6 \\
\hline NVQ1 & 8.8 & 55.1 \\
\hline No degree & 19.3 & 40.2 \\
\hline \multicolumn{3}{|l|}{ Married } \\
\hline Men & 37.4 & 70.5 \\
\hline Women & 31.9 & 67.0 \\
\hline \multicolumn{3}{|l|}{ Union } \\
\hline Coverage & 48.4 & 76.9 \\
\hline Membership & 32.5 & 76.4 \\
\hline Full-time workers & 74.7 & 74.6 \\
\hline Workers with a permanent job & 82.4 & 72.2 \\
\hline Self-employed persons & 11.1 & 48.5 \\
\hline \multicolumn{3}{|l|}{ Occupations } \\
\hline Managers and administrators & 14.6 & 83.7 \\
\hline Professionals & 10.5 & 93.8 \\
\hline Associate professionals & 10.4 & 86.4 \\
\hline Clerical and secretarial & 16.5 & 95.8 \\
\hline Craft and related & 12.2 & 55.3 \\
\hline Personal and protective services & 10.5 & 45.2 \\
\hline Sales & 7.1 & 68.8 \\
\hline Plant and machine operatives & 0.7 & 42.8 \\
\hline Other & 7.5 & 17.9 \\
\hline
\end{tabular}


Appendix. Continued

\begin{tabular}{lcc}
\hline Variable & $\begin{array}{c}\text { Percentage in } \\
\text { survey }\end{array}$ & $\begin{array}{c}\text { Percentage } \\
\text { computer users }\end{array}$ \\
\hline Sectors & 1.5 & 37.8 \\
$\quad$ Agriculture, forestry, and fishing & 4.2 & 53.4 \\
Energy and water supply & 9.3 & 70.9 \\
Extraction of minerals & 6.7 & 72.7 \\
Metal goods, engineering, and vehicles & 7.1 & 58.0 \\
Other manufacturing & 17.7 & 65.4 \\
Construction & 11.8 & 75.9 \\
Distribution, hotels and catering, repairs & 16.6 & 82.4 \\
Transport and communications & 20.1 & 68.8 \\
Banking, finance, insurance, and business & 5.1 & 55.2 \\
Other services & & \\
\hline
\end{tabular}

Notes: All data are taken from the Skills Survey of the Employed British Workforce. $n=2,421$. Occupational categories are based on the Standard Occupational Classification and classification of sectors on the Standard Industrial Classification.

\section{Notes}

${ }^{1}$ Other explanations have been that the higher wages are due to unobserved heterogeneity (DiNardo and Pischke, 1997), that high-wage workers receive computers first because of advantages in other skills complementary to computer use (Levy and Murnane, 1996), because time-saving investments are more valuable when wages are high (Borghans and ter Weel, 2004a, 2006), and that firms using computers pay higher wages (Chennells and Van Reenen, 1997; Doms et al., 1997; Entorf and Kramarz, 1997; Entorf et al., 1999). Autor et al. (1998), Borghans and ter Weel (2005), and Katz and Autor (1999) review this literature extensively.

${ }^{2}$ For example, a worker who never used email is probably not able to use this computer application instantly. After a couple of days, or taken part in a course on how to operate the PC and the software, the worker is likely to be able to send and process emails effectively. However, it seems to be unlikely that the employer is going to pay this worker for having acquired the computer skills to operate the PC and the email software.

${ }^{3}$ Ashton et al. (1999) provide a detailed overview of the data, its collection, and the design of the questionnaire.

${ }^{4}$ Other analyses using UK data are performed by Dickerson and Green (2004), Dolton and Makepeace (2004), and Green et al. (2003). They present analyses of the returns to computer use for the UK and argue that its returns are nonnegligible and likely to be a reflection of computer literacy. Chennells and Van Reenen (1997) use the UK Workplace Industrial Relations Survey data to analyse computer adoption over time. They find that it is not so clear whether the returns to computer use are to be interpreted in this way. In particular, they find that computer users did not experience substantial wage increases when adopting computer technology, casting doubts about the interpretation of the returns to computer use. 
${ }^{5}$ The answer 'not at all important' is reported if workers do not use a computer at work.

${ }^{6}$ Note that the design of the survey is such that questions on the level of sophistication and effectiveness of computer use have not been asked to people who indicate that they do not use computer technology at work.

${ }^{7}$ See Spenner (1990) for a discussion of these kinds of data problems and Bertrand and Mullainathan (2001) for a summary of the literature using such measures and the integration of data into a measurement-error framework as to understand what they imply for empirical research relying on subjective data.

${ }^{8}$ Borghans and ter Weel (2004b) offer a more formal treatment of how to estimate this model.

${ }^{9} \mathrm{We}$ also investigated equations including information about tenure, whether the job a worker occupies is temporary or permanent, the number of hours worked and the number of hours worked squared. Although all estimates on these variables are significant at the 5 per cent level, they do not change the overall picture presented in Table 4 . We have also run regressions for men and women separately. Again the magnitude of the results does not change significantly; in a similar regression as the one reported in column 2, the coefficient (standard error in brackets) for men equals 0.197 (0.037) and for women $0.173(0.032)$. The results of taking into account the importance, level of sophistication, and effectiveness of computer use (as shown in columns 3-5 of Table 4) are also comparable if we include additional variables and run separate regressions for male and female workers.

${ }^{10}$ See, for example, Krueger (1993) for the USA and DiNardo and Pischke (1996) for Germany. Only including the dummy variable for computer use and an intercept leads to an estimated wage differential between workers who use computers and workers who do not of 57.6 per cent.

${ }^{11}$ See also Borghans and ter Weel (2004b) for a more detailed analysis of the returns to cognitive skills.

\section{References}

Ashton D., Davies B., Felstead A. and Green F. (1999) Work Skills in Britain, Oxford: ESRC Centre on Skills Knowledge and Organizational Performance (SKOPE), Oxford and Warwick Universities.

Autor D. H., Katz L. F. and Krueger A. B. (1998) 'Computing Inequality: Have Computers Changed the Labor Market?', Quarterly Journal of Economics 113: 1169-1213.

Autor D. H., Levy F. and Murnane R. J. (2003) 'The Skill Content of Recent Technological Change: An Empirical Exploration', Quarterly Journal of Economics 118: 1279-1333.

Bell B. D. (1996) 'Skill-biased Technical Change and Wages: Evidence from a Longitudinal Data Set', Nuffield College, Mimeo, July.

Berman E., Lang K. and Siniver E. (2003) 'Language Skill Complementarity: Returns to Immigrant Language Acquisition', Labour Economics 10: 265290.

Bertrand M. and Mullainathan S. (2001) 'Do People Mean What They Say? Implications for Subjective Survey Data', American Economic Review 91: $67-72$. 
Borghans L. and ter Weel B. (2002) 'Do Older Workers Have More Trouble Using a Computer than Younger Workers?' Research in Labor Economics 21: 139-173.

Borghans L. and ter Weel B. (2004a) 'What Happens When Agent $T$ Gets a Computer? The Labor Market Impact of Cost Efficient Computer Adoption', Journal of Economic Behavior and Organization 54: 137151.

Borghans L. and ter Weel B. (2004b) 'Are Computer Skills the New Basic Skills? The Returns to Computer, Writing and Math Skills in Britain', Labour Economics 11: 85-98.

Borghans L. and ter Weel B. (2005) 'How Computerization has Changed the Labour Market: A Review of the Evidence and a New Perspective' in Soete L. and ter Weel B. (eds.) The Economics of the Digital Society, Aldershot: Edward Elgar: 219-247.

Borghans L. and ter Weel B. (2006) 'The Division of Labour, Worker Organisation, and Technological Change', Economic Journal 116: F45-F72.

Borjas G. J. (1994) 'Self-selection and the Earnings of Immigrants', American Economic Review 77: 531-553.

Chennells L. and Van Reenen J. (1997) 'Technical Change and Earnings in British Establishments', Economica 64: 587-604.

Chiswick B. R. and Miller P. W. (1995) 'The Endogeneity between Language and Earnings: International Analyses', Journal of Labor Economics 13: 246-288.

Dickerson A. and Green F. (2004) 'The Growth and Valuation of Computing and Other Generic Skills', Oxford Economic Papers 56: 371-406.

DiNardo J. and Pischke J.-S. (1996) 'The Return to Computer Use Revisited: Have Pencils Changed the Wage Structure too?', NBER Working Paper 5606, June.

DiNardo J. and Pischke J.-S. (1997) 'The Return to Computer Use Revisited: Have Pencils Changed the Wage Structure Too?', Quarterly Journal of Economics 112: 291-303.

Dolton P. and Makepeace G. (2004) 'Computer Use and Earnings in Britain', Economic Journal 114: C117-C129.

Doms M., Dunne T. and Troske K. R. (1997) 'Workers, Wages and Technology', Quarterly Journal of Economics 112: 253-290.

Dustmann C. and van Soest A. (2001) 'Language Fluency and Earnings: Estimation with Misclassified Language Indicators', Review of Economics and Statistics 83: 663-674.

Entorf H. and Kramarz F. (1997) 'Does Unmeasured Ability Explain the Higher Wages of New Technology Workers?', European Economic Review 41: 1489-1509.

Entorf H., Gollac M. and Kramarz F. (1999) 'New Technologies, Wages and Worker Selection', Journal of Labor Economics 17: 464-491.

Green F., Felstead A. and Gallie D. (2003) 'Computers and the Changing Skillintensity of Jobs', Applied Economics 35: 1561-1576.

Hamilton B. H. (1997) 'Returns to Computer Skills and Black-White Wage Differentials', John M. Olin School of Business, Mimeo, March.

Katz L. F. and Autor D. H. (1999) 'Changes in the Wage Structure and Earnings Inequality' in Ashenfelter O. and Card D. (eds.) Handbook of Labor Economics, Amsterdam: North-Holland: 1463-1555. 
Krueger A. B. (1993) 'How Computers Have Changed the Wage Structure: Evidence from Microdata, 1984-1989', Quarterly Journal of Economics 108: 33-60.

Levy F. and Murnane R. J. (1996) 'With What Skills Are Computers Complements?', American Economic Review 86: 258-262.

OECD (2000) 'Adult Literacy and Life Skills: Computer Literacy', OECD, Mimeo, November.

Spenner K. I. (1990) 'Skill: Meaning, Methods and Measures', Work and Occupations 17: 399-421.

Willis R. J. and Rosen S. (1979) 'Education and Self-selection', Journal of Political Economy 87: 517-536. 